KAWISTARA

VOLUME 6

No. 1, 21 April 2016

Halaman 1-112

\title{
Memahami Yang Lokal: Jalan Untuk Membentengi Yang Suci
}

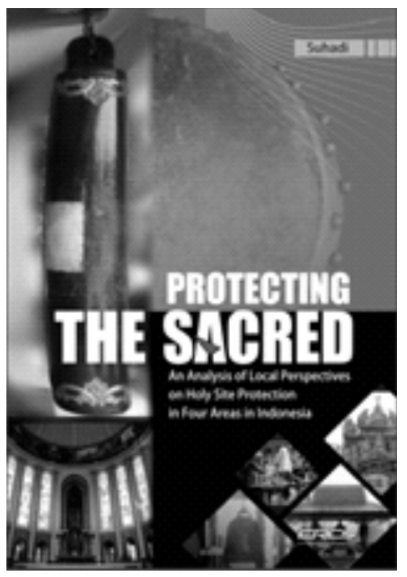

Judul Buku

Penulis

Penerbit

Tebal

resensi

\author{
Protecting The Sacred \\ Suhadi \\ : CRCS (Center for Religious and Cross Cultural Studies) \\ 94 halaman \\ Ali Jafar*
}

Sudah tidak diragukan lagi bahwasa Indonesia adalah negara dengan mayoritas muslim terbesar di dunia. Dengan lebih dari 85\%, Muslim Indonesia mendominasi hampir seluruh wilayah pelosok tanah air. Akan tetapi, wajah Indonesia tidaklah homogen seperti dalam angka-angka statistika, selain terdapat enam agama yang diakui, Indonesia juga kaya akan keberagaman kepercayaankepercayaan lokal yang tidak pernah disebutkan dalam angka.

Keberagaman kepercayaan lokal yang oleh negara hanya diakui sebagai kebudayaan sehingga dalam praktiknya, pemahaman tentang keagamaan dan kebudayaan sering tumpang tindih. Sementara itu, pertemuan antara agama-agama yang diakui di Indonesia membawa dinamika dan tantangan tersendiri terhadap aturan pembangunan tempat ibadah, toleransi, dan pemahaman terhadap 'yang lain".

Melihat permasalahan di atas, buku Protecting The Sacred berusaha menunjukan akan adanya permasalahan yang serius terhadap intoleransi dan dinamika keberagaman. Buku tersebut merupakan hasil kajian lapangan dari berbagai 422 narasumber di empat wilayah di Indonesia, yaitu Bekasi, Bali, Manado, dan Pontianak. Empat wilayah ini dipilih sebagai sampling yang representatif terhadap dinamika pembangunan tempat ibadah yang dalam catatanya pernah mengalami masalah. Meskipun demikian, sampling ini tidak mewakili Indonesia secara keseluruhan karena luasnya

* Mahasiswa Agama dan Lintas Budaya Sekolah Pascasarjana Universitas Gadjah Mada konteks keindonesiaan. Pada bagian pertama buku ini, beberapa permasalah intoleransi, universal kode tentang pembangunan tempat ibadah dengan segenap dinamika yang ada. Ada dua pertanyaan mendasar yang diajukan dalam buku ini, pertama dalam hal apa kode etik pembangunan tempat ibadah dapat dijadikan alat untuk mempromosikan dan membentengi tempat-tempat yang disucikan; Kedua bagaimana pemahaman dan persepsi publik terhadap tempat ibadah itu.

Pada bagian kedua, tulisan ini awalnya mengulas tentang universal kode tentang pembanggunan tempat suci (the Universal Code of Conduct on Holy Site-UCCH). Berdasarkan temuan lapangan yang ada, ada dua pemahaman terhadap tempat suci sebagai berikut: (1) sebagai tempat ibadah, (2) sebagai tempat ziarah. Akan tetapi, pemahaman terhadap yang suci sebagai situs keagamaan atau kebudayaan. Mayoritas respondents, $58 \%$, memahami situs suci sebagai situs keagamaan dan situs kebudayaan sekaligus. Sehingga banyak sekali situs-situs kebudayaan yang juga difungsikan sebagai tempat peribadatan. Seperti Masjid Al-Hikmah 
di Bali yang arsitekturenya menyesuaikan dengan bangunan di Bali. Klenteng Hok Lay Kong dan Vihara Buddha Dharma di Bekasi yang mengalami masalah yang lain ketika Konghucu diresmikan sebagai agama resmi di Indonesia.

Beberapa situs suci menunjukan adanya penyesuaian agama dengan kebudayaan masyarakat setempat serta kehidupan yang harmoni di mana satu tempat suci dari satu agama berdekatan dengan tempat suci dari agama yang lain. Meskipun demikian, tempat-tempat suci ini tidak dapat bebas begitu saja dari konflik yang ada. Beberapa tempat suci yang difungsikan sebagai tempat ziarah sering dianggap sebagai praktik sinkretis antaragama. Seperti dalam kasus Watu Pinawetengan di Sulawesi Utara yang dianggap mencampur adukan ajaran Katholik, dengan budaya lokal.

Pada bagian ketiga, buku ini mengulas tentang perubahan sosial, hubungan antaragama dan pemeliharaan terhadap situssitus suci. Indikator yang dibangun adalah relasi antaragama. Dari wawancara yang dilakukan, ada sekitar $82 \%$ responden yang memiliki hubungan pertemanan dengan agama yang lain. Indeks terendah ada pada Bekasi di mana hanya 69\% responden yang memiliki teman dari agama lain. Dukungan tehadap situs suci agama lain, terdapat $63 \%$ yang mengatakan setuju, sementara situs suci dari kepercayaan lokal hanya mendapatkan 58\%. Dari angka-angka yang ada menunjukan bahwa tingkat toleransi terhadap situs suci agama yang sudah diakui lebih besar dari pada agama yang belum diakui. Meskipun demikian, angka toleransi yang tinggi menunjukan adanya kesadaran terhadap keberagaman.
Pada kasus di Bali terdapat banyak kasus marginalisasi terhadap orang migran, tetapi adanya pertemuan kebudayaan telah membawa pada masyarakat yang lebih toleran. Pada bangunan Bale Banjar di mana berawal dari hanya di disain untuk masyarakat Hindu lokal, telah diinisiasi kembali menjadi bangunan yang lebih pluralis setelah pertemuan kebudayaan antarmasyarakat. Buku ini mengutip penelitian dari Reza Pangabean di mana masyarakat memiliki peranan yang sangat penting dalam menjaga kerukunan. Dalam kasus kekerasan di Ambon, tidak terjadi di Manado. Hal ini karena keterlibatan masyarakat sipil di Manado dalam menjaga kerukunan. Selain faktor masyarakat, kampanye terhadap toleransi, dan perlindungan situs-situs suci juga memiliki peranan penting. Diperlukan dialog yang intensif dan keterlibatan berbagai pihak untuk menciptakan masyarakat yang toleran, termasuk peranan wanita. Peranan wanita menjadi penting karena berdasarkan analysis quantitative yang ada, wanita memiliki pandangan yang lebih positif terhadap keberagaman.

Buku ini cukup penting untuk melihat bagian kecil dari Indonesia dalam menyikapi keberagaman keagamaan-kebudayaan, toleransi, dan upaya untuk melindungi tempattempat suci. Sistematika pembahasan cukup rapi dan dengan menjadikan empat tempat sebagai studi kasus, buku ini membawa pembaca pada pemahaman yang berbeda terhadap nilai-nilai lokal dalam menjaga tempat-tempat suci. Akan tetapi, buku ini tidak dapat digunakan untuk membaca Indonesia secara keseluruhan. Hal yang perlu ditambahkan mungkin adalah cakupan tempat yang lebih banyak dan luas, sehingga dapat membaca Indonesia lebih dekat. 